\title{
From Scepticism to Liberalism? Bernard Williams, the Foundations of Liberalism and Political Realism
}

\author{
Paul Sagar \\ King's College Cambridge
}

Bernard Williams was an ethical sceptic, but he was also a proponent of liberalism. To what extent can one finally be both? This article explores this question through a particular emphasis on Williams, but seeks to draw wider lessons regarding what ethical scepticism should and should not amount to. It shows how ethical scepticism can be reconciled with a commitment to what Williams, following Judith Shklar, called 'the liberalism of fear', which is revealed as an ecumenical outlook for different stripes of ethical sceptic. The article concludes by drawing some lessons for the recent 'realist' turn in political theory.

Keywords: Bernard Williams; scepticism; liberalism; liberalism of fear; political realism

\section{Introduction}

Bernard Williams was an ethical sceptic. By this I do not mean that he thought our ethical lives devoid of value. No sane person ought to think that, and certainly Williams did not. But he did believe that there are no ultimate - we might say, metaphysical - supports of what we value. There is no point of view of the universe, no God, no natural teleology, no transcendental Kantian rationality, guaranteeing that what we do is ultimately right, good, correct, or otherwise. Yet Williams was also a proponent of liberalism. This invites a simple question, albeit one that yields anything but simple answers: How could Williams have been an ethical sceptic and a liberal?

As is presently the focus of much attention, Williams's liberalism differed from what he dubbed the 'political moralism' of much existing liberal philosophy - especially that of John Rawls and Ronald Dworkin - conceiving of politics in a more 'realistic' vein, one seeking to 'ground' liberalism in 'an approach which gives greater autonomy to distinctively political thought' (Williams, 2005, p. 3). According to Williams, politics could not be a function of, or simply operate under the dictates laid down by, moral philosophy, but must be understood on its own terms, exhibiting sometimes problematic relationships to our ethical commitments (Williams, 1981; 2005, pp. 1-17). Barrels of ink are being spilled on the subject of 'realism' in political philosophy ${ }^{1}$ - much of it on Williams's particular version. ${ }^{2}$ I will have something to say about that matter at the end of this article, but my primary focus is on the questions of whether and how a commitment to liberalism can be coherently sustained without a 'grounding' in what we value.

We may begin by considering the following. It is both true, and something to be thankful for, that scepticism regarding the lack of ultimate support for what we do and value does not in practice undermine what we do and value. The universe may not care that you lied to me, but then the universe clearly does not realise how much it upset me 
that you did so - and hence so much the worse for the universe. A venerable tradition of philosophical thinking, articulated especially in the philosophy of David Hume and his admirers, suggests that, with regard to politics, matters are no different than with our ordinary ethical interactions. It would be at the very least a bizarre reaction to the sufferings of the world to claim that because one cannot metaphysically invalidate them one should doubt whether one has reason to think and act in ways relating to those to which we are not already closely tied sentimentally. By contrast, if one feels cruelty to be - as Judith Shklar claimed, and Williams sympathised - the worst thing people can do, then ipso facto one has reason to endorse a conception of politics that aims to reduce cruelty (Forrester, 2012; Shklar, 1984; 1998). Metaphysics has nothing to do with it.

Legitimate doubts may nonetheless remain. Political philosophy provides justifications as well as explanations, in particular for the use of violence and coercion over others. It thus makes complexly value-laden claims. Yet if the ethical sceptic believes such claims cannot be validated beyond what people like us happen to be doing due to our contingent historical formation, a worry may arise that there is something deeply problematic in any project of providing political justifications, including those taking a liberal form. This article explores what such a worry should and should not amount to.

Williams is a particularly useful guide in these matters, in part because his ethical writings of the 1980s appear to eschew a Humean outlook of the sort just sketched. In Ethics and the Limits of Philosophy, he claimed that our no longer being able to believe in a natural teleology underpinning our ethical practices (as Aristotle did) opens up a gap between 'the agent's perspective' and the possibility of an 'outside view'. But with 'that gap opened, the claim I expressed by saying that agents' dispositions are the "ultimate supports" of ethical value takes on a more skeptical tone. It no longer sounds enough'. Williams emphasised the inadequacy of modern moral philosophy to make do without something like Aristotle's teleology, despite having inherited from Aristotle a description of our ethical condition that was broadly correct: '[T] he Aristotelian assumptions which fitted together the agent's perspective and the outside view have collapsed. No one has yet found a good way of doing without those assumptions' (Williams, 1993 [1985], pp. 52-3).

Simon Blackburn, reviewing Ethics and the Limits of Philosophy, directly challenged Williams's insistence on such a gap, and asked why he did not consider Hume as a non-teleological alternative to Aristotle on the sentimentalist grounds sketched above (Blackburn, 1986). Williams replied that he took Hume to be primarily in the business of providing explanations of how our moral practices come about, and that as well as finding these explanations implausible, he believed that Hume's sociologically based accounts of moral practice could not provide an answer to the individual ethical agent pressing the question of why they should act ethically at any precise moment. Williams further rejected Hume as being too complacent in his assumptions of the uniformity of moral practice, making him a poor guide to the specifically modern problems of ethical diversity and conflict. Williams in turn made no secret of his dislike of what he took to be Hume's comfortableness within his own ethical outlook: his hope that ethics could be everything it appeared to be, against Williams's insistence that what made ethics so difficult and interesting was precisely that it could not be everything it seemed (Williams, 1986; 1993 [1985] pp. 135 and 199). 
Yet we must tread carefully. Williams's rejection of Hume is specific in its nature, relating especially to what he takes to be Hume's over-reliance on faulty explanations and insensitivity to the diversity of ethical practice. It might be tempting to infer that because Williams rejected Hume's particular variant of a reconciling project between the lack of ultimate support for our values and our commitment to those values, that Williams was therefore himself committed to a stronger variant of ethical scepticism that rejected the possibility of success for any such project. But this is not the only way to read the claim that nobody, including Hume, has yet found a good way to do without the assumptions that fitted Aristotle's worldview together and can thus reconcile us to the fact there is only our internal perspective from which to think and judge. An alternative reading is that Williams is suggesting that our task at present is to try to do a better job of doing without those assumptions than has hitherto been managed. Williams can thus be read as rejecting Hume's specific account, while holding out for the possibility of constructing an alternative (and by his lights more successful) form of reconciling project.

In this article I explore these possibilities with a particular emphasis on how different assessments of what follows from the lack of ultimate support for our values might affect commitment to liberalism as a form of politics. More specifically, I examine how Williams argued for a more distinctively 'realist' political philosophy than that widely on offer at the turn of the twentieth century, which, following Shklar, he called the 'liberalism of fear': a minimalist form of liberalism concentrating on damage control and the reduction of cruelty in the context of the catastrophic failures of modern political systems in recent historical memory. After examining Williams's account of the liberalism of fear I return to the question of ethical scepticism and suggest that Williams is best read as offering an alternative to Hume, while rejecting a more thoroughgoing scepticism that might also be considered. Ultimately, I aim to show that the liberalism of fear is open to those who diverge from Williams's particular assessment of how one should respond to the lack of ultimate support for our values, meaning it is an ecumenical outlook for different stripes of ethical sceptic. I conclude by considering some consequences of this for the recent 'realist' turn in political theory.

\section{Williams's Liberalism}

Due to its scattered and often posthumously published nature, Williams's political theory is not as clear as we might hope to make it, and indeed has been liable to some misinterpretation as a result. Once we are clear on the proper nature of Williams's liberalism, we can then focus upon the question of the consistency between this and his ethical scepticism. What follows in this section is an attempt to explicate what I take to have been the fundamental shape and content of Williams's liberalism. In some dimensions I must go beyond what Williams explicitly said, and reconstruct what I interpret him to have meant. This is done in a spirit of honesty and holistic interpretation; it is a way of making clearer a political philosophy that Williams did not live long enough to formalise and fully substantiate, but which is more cogent and integrated than it might seem.

We can begin by asking: Why should we be liberals? This question is immediately liable to mislead, and must be handled carefully. It implies that we pick and choose our political values from some independent position outside those values, as if we do not come to them 
already (at least) partly formed through years of socialisation, education and political experience. Granted that pre-formation in political value prior to worthwhile reflection is a given for every normal adult human, we may press the question. I take one of Williams's central suggestions to be that in significant measure we should be liberals because many of us already are, given who and what we must be, in Williams's phrase, 'now and around here'.

To see this better we can begin by considering a central item in Williams's political thinking: the 'basic legitimation demand' (BLD) (Williams, 2005, pp. 4-6). The BLD is what must exist if there is to be such a thing as politics: the requirement that something be said to those subject to organised violence. If nothing is said, we are in a situation of unmediated coercion, of warfare. (This can be internal as well as external, as when the Spartans coerced the Hellots without offering any justification to the Hellots of what they were doing.) For a situation of warfare to end and politics to begin, the group being coerced must be offered some kind of justification for why it is on the receiving end of violence. This justification is presented as something the victim group is expected to be able to recognise as making a claim on them, and is engaged with as such, even if only to be rejected. Absent this, there is only unmediated coercion, and that is what politics is in the first instance supposed to replace, to be an attempted solution to. Crucially, a given justification does not have to be accepted by the victim group(s). The point is not that everybody subject to a locus of political power sees that power as legitimate and accepts any and all coercive directives it issues. ${ }^{3}$ It is that the locus of political power offers what it is doing as not just coercion, but as something that ought to be accepted by the victims, and in the right kind of way by their own lights, even if it isn't (Williams, 2005, pp. 135-6).

It is a serious mistake of Williams's critics to suppose he implicitly relied upon some (unrealistic, fantastical) consensus view of politics whereby states are only legitimate if all those subject to its power accept it as such (Freeden, 2012; Rossi, 2013; Sleat, 2010). His was a more basic analytic contention that in order for there to be such a thing as politics at all, something has to be said to those being coerced. The BLD is a demand, and whether the answer given to that demand is found acceptable is a further question. Williams's invocation of the BLD is intended to delineate when politics is happening, identifying the attempted justification of power by one group over another as the starting point (Hall, forthcoming).

If sufficient numbers of people accept the legitimation story offered by a locus of political power for the exercise of coercion it can be said to have achieved legitimacy. This is not legitimacy according to some timeless external standard imposed by Williams, but legitimacy as conferred by people within that situation. If the legitimation story is rejected by sufficient numbers, the locus of political power will be considered illegitimate. The point is that in both cases we have grounds for saying that politics is happening as opposed to mere warfare because of the recognition of the BLD and the actualised need to answer it. In extreme cases of illegitimacy things may get so bad as to be almost indistinguishable from war, and indeed may disintegrate into it. But the difference is clear in principle, if inevitably not always in practice.

For Williams, 'now and around here' the only acceptable answer to the BLD yielding a legitimate answer is liberalism. This is a complicated claim, and much turns on our 
understanding it correctly. I take Williams, in his self-confessedly crude slogan that 'LEG [legitimacy] + Modernity = Liberalism', to have meant the following (Williams, 2005, p. 9). In terms of political arrangements able to offer a justification for the exercise of coercive political power over their subject populations, for contemporary Western peoples only liberalism at present successfully achieves this and has a realistic prospect of continuing to do so. In no small measure this is because liberal politics, through its interrelation with capitalist production and exchange, is able to consistently, and so far permanently, not only put food on tables, but deliver high levels of material prosperity for large sections of ruled populations. Yet it is also because of its (as Shklar put it) 'monogamous marriage of convenience' to democracy that ensures redress mechanisms whereby populations can prevent and remove the worst abusers of coercive power (Shklar, 1998, p. 19). Due precisely to its marriage to relatively high and relatively stable economic and democratic prosperity, liberalism is able to secure its populations against the worst excesses of military and economic disaster. For those reasons, liberalism 'makes sense' as a solution to the BLD, 'now and around here' (Williams, 2005, pp. 7-12).

A glance at history indicates just how poor liberalism's rivals turned out to be at making sense, to the point where they are largely gone from Europe and never seriously existed in North America. Yet liberalism doesn't have to 'make sense' everywhere. It didn't make sense in medieval Saxony, and it doesn't (at least, not fully) make sense in contemporary China. But Williams was not talking to medieval Saxons or contemporary Chinese about the reasons people like us, now and around here, have to be liberals. The extent to which one believes Williams was right in thinking that liberalism could only be, but also need only be, a political outlook for those already living under its arrangements will significantly determine the extent to which one finds his perspective conducive to an adequate theory of politics. (Those who find it inadequate will be faced with the daunting task of articulating a liberalism of universality in the face of intransigent historical and geographic disagreement and opposition - something that, Williams was keen to point out, proponents of more ambitious liberalisms consistently fail to even attempt.)

Williams's approach, unlike more moralistic forms of liberalism, need offer no theory of error in explaining why the allegedly universal truths of liberalism have only become evident to relatively small numbers of humanity in some parts of the world from the late seventeenth century onwards. For on Williams's view there is no error for a theory to explain. Liberalism is not a timeless moral truth, but an historically contingent and localised achievement - and there is, at the first-order level of political organisation at least, nothing wrong with it being that (we will return below to whether there is something wrong at a second-order level of critical evaluation). Connectedly, Williams claimed that non-liberal forms of society have been, and perhaps still can be, legitimate answers to the BLD, even if they are not for us 'now and around here', due to their being based on mythical, false or ideological justifications such as divine right, or the inherent superiority of a social, racial or religious class.

Although liberalism makes sense as a solution to the BLD, and is presently the only political form 'now and around here' that can be said to do so, it does not follow on from Williams's analysis that all who live under liberal institutions must therefore be liberals. For some - socialists, Marxists, communitarians, republicans, even reactionary conservatives 
and perhaps even intelligent fascists - liberalism makes sense by virtue of being an actualised system under which they have daily experience of living. But non-liberals will believe that despite operating as an answer to the BLD, the problems exhibited by liberalism are so serious as to mean we would be better off if it were (eventually, somehow) replaced. In this way, other forms of political organisation 'make sense' to non-liberals. Non-liberals must accept that they are faced with the unenviable task of both articulating, and presumably somehow enacting, a vision of political order that is both non-liberal and that makes more sense than the current dominant liberal solution to the BLD, ${ }^{4}$ and which could realistically be expected to replace it. ${ }^{5}$ This is not impossible, but part of the point of Williams's appeal to Shklar's polemical argument consisted of reminding both liberals and non-liberals of the catastrophic humanitarian failures of non-liberal regimes in the twentieth century, encouraging significant caution with regard to radical political aspirations. This is not to say that from a perspective like Williams's liberalism is by any means perfect, or even always ethically palatable. The American management of its 'backyard' in Latin America, for example, shows that in foreign policy terms especially, liberal regimes can be extremely unpleasant. In international relations Williams was sensitive to the extreme limitations of political aspirations focused on the minimal imperative of damage control (Williams, 2005, pp. 145-53). Yet domestically speaking at least, Williams's point, following Shklar, was that liberal regimes possess by some distance the best track record in not tyrannising their populations. That is in large measure why they overwhelmingly make the most sense 'now and around here', and why after the bloodbath of the twentieth century they are the only real option for people like us.

The fact that liberalism already makes the most sense 'now and around here' is especially important to Williams's view because of his insistence that we cannot choose what makes sense to us (Williams, 2002, pp. 233-69; 2006a pp. 331-7). In turn, although we can and should be reflective about our ethical and political commitments and must change those when necessary, in significant measure they, and our ability to change them, will be determined by what makes sense to us - which is out of our control. Some have seen this as threatening to undermine our ethical and political practices. If we cannot ultimately choose them, how can they be ours; how can they be worth what we think they must be worth? Williams insisted that this is a mistake: it is false to believe there is or could be some outside point of view from which we could choose our commitments and values. Even if there were, it would not be us who chose those commitments and values, because we need such things to be in place before we can do any choosing. We do not need choice to go all the way down, and accordingly we can do without the more extravagant - typically Kantian and Rousseauian - forms of contemporary liberal political philosophy demanding that everything deemed legitimate be traceable to conditions of freely chosen agency. On Williams's account, liberalism need not make thick appeals to autonomy in order to ground itself, and indeed will be better off, as well as more accessible to sceptics about both autonomy and liberalism, without such appeals (Williams, 2005, pp. 73-4).

Any individual to whom liberalism 'makes sense' as a solution to the BLD 'now and around here', and who finds non-liberal alternatives either unrealistic or undesirable, already has considerable reasons to be a liberal. More precisely: to a significant extent such an agent will already be a liberal, at least in terms of basic dispositions and outlooks. We come 
to our political beliefs through years of conditioning, socialisation and formation, first before, and then during, our earliest years of reflection. Certainly we can reflect upon and alter our views. Those who do not do this have something to worry about, and in the worst cases they give others something to worry about too. But accepting the fact that many of us will have liberal outlooks and dispositions by the time we reach the point of critical reflection, the correct question on Williams's outlook is whether a disposition to liberalism should survive critical reflection, rather than (mistakenly) supposing ourselves to be starting from nowhere and picking liberalism as the best option from an array of equally intelligible and possible alternatives.

Such critical reflection might take at least two forms. The first regards the content of liberal practice understood at a first-order level - i.e. the question of why we should support certain ways of doing politics and not others. Williams offered a deliberately capacious understanding of liberalism as the endorsement of a form of society that 'aims to combine the rule of law with a liberty more extensive than in most earlier societies, a disposition to toleration, and a commitment to some kinds of equality' (Williams, 2002, p. 264). When living under such a regime, we can (and indeed do) ask why we want these sorts of practices and not their historical, theoretical or geographical alternatives. Williams's answer (following Shklar) was that ultimately we want such arrangements because they do the best job of minimising cruelty. In particular, when solving the 'first political question' of how to prevent bare domination - i.e. instantiating politics as opposed to war - liberal regimes do the best job of preventing the solution from lapsing into the problem. (Williams agreed with Locke that Hobbes's major failing is that his solution rapidly becomes the problem, and so we need a political theory that gets beyond Hobbes [Williams, 2005, pp. 3-4]). In turn, liberal regimes are best placed to facilitate the politics of hope and aspiration once the conditions of order and security have been achieved: the liberalism of fear need not be the politics of despair.

There may be a second-order level of critical reflection, which steps back from these more immediately pressing concerns and asks: What does it mean for us to value a politics that reduces cruelty, and why should we want those sorts of values and not something else? It is here that the question of how one can be an ethical sceptic and a liberal comes clearly into focus. Yet examining matters at this point also allows us to appreciate Williams's central suggestion that it is a serious mistake to think that there is indeed any separate, second-order level of critical reflection with potentially destabilising implications for ethical and/or political practices tout court. As I show in the next section, Williams's scepticism was of a much more focused and specific kind.

\section{Liberalism and Scepticism}

A significant feature of Williams's position as reconstructed above is that the first-order level it is ecumenical with regard to philosophical positions likewise sceptical of founding liberalism in more thoroughgoing moral commitments. ${ }^{6}$ A Humean outlook can straightforwardly endorse the liberalism of fear at the first-order level in terms of a sentimental aversion to cruelty and domination and our empathic engagement with the victims of such practices, without the need to invoke more complex, demanding or abstract moral principles. Simon Blackburn has previously offered just such an account (Blackburn, 1998, 
pp. 269-78). Similarly, Williams's emphasis on the importance of preventing cruelty as the main reason to support liberal regimes is compatible with Richard Rorty's insistence that despite taking an 'ironic' stance of detachment when thinking about liberalism in a critical philosophical mode, in the mode of practical political engagement an aversion to cruelty and domination is exactly what does and should motivate a commitment to liberal politics (Rorty, 1989, pp. 73-95).

Yet, as we have seen, Williams rejected Hume's outlook. And it is well known that he dismissed Rorty's irony as incoherent and self-refuting. What was his alternative? By examining Williams's rejection of Rorty we can get a better grip on the nature of his scepticism, and see how Williams differentiated his view from a more thoroughly Humean outlook. This allows us to understand properly how Williams combined (a mitigated form of) ethical scepticism with a commitment to the liberalism of fear, as well as considering the options that remain for more thoroughly sceptical outlooks than Williams avowed.

According to Rorty, as philosophers we ought to take an 'ironic' stance to questions of value in our intellectual pursuits, detaching ourselves from searches for truth and accepting that right and wrong are determined by pragmatic standards of usefulness within a contingent 'vocabulary' used to order and manipulate the world. Yet in our practical lives we endorse liberalism as a block to cruelty and humiliation (universal human wrongs), suspending the 'ironic' perspective to support liberalism. However, as Williams and Blackburn point out, Rorty's position suffers from several debilitating problems (Blackburn, 1998, pp. 287-94; 2005 pp. 151-6; Williams, 2002, p. 59, 128 and 147-8; 2006b, pp. 192-4). In particular, irony cannot be coherently married to a practical commitment to liberal values. If something counts as getting it right (and both Williams and Blackburn insist, against Rorty, that not only is this true, but that it better had be if there is to be such a thing as philosophy at all), even if we find that there are no ultimate supports of what we do and value, it does not follow that we should view all answers equally by adopting ironic detachment. Some answers remain better than others, and 'conversation' is not all that we should hope for. Furthermore, if we genuinely assume ironic detachment, we cannot maintain a liberal attachment to practical values and principles. One or the other has to give. If we accept irony, we cannot consistently go on maintaining a commitment to liberal values over others. If we do maintain such a commitment we are not really ironic but think that something counts as getting it right after all - which, unsurprisingly, happens to be what we value (Williams, 2006b, p. 193). ${ }^{7}$

It is helpful to examine Williams's response to another philosopher he believed exhibited the same fundamental mistakes as Rorty. Williams rejected Bertrand Russell's both 'selfpitying and at the same time self-glorifying rhetoric' to the effect that because there is no point of view of the universe from which to invest human activity with meaning, we are therefore without meaning. This generates, Williams claimed, an outlook that 'can make people feel that human activities are absurd, because we invest them with an importance which they do not really possess' (Williams, 2006b, p. 137). He insisted that this was 'a muddle' between thinking that our activities fail some cosmic test of significance and thinking that there is no such test - the point being that because there isn't any such test we are muddled if we feel melancholy at the thought either of failing it or of it not being there. In questions of value there is no absolute point of view, no point of view of the 
universe, but only our particular human point of view, and it is only from that point of view that we can make non-muddled assessments (or any assessments at all) of the value of what we are doing.

Nietzsche by contrast got it right when he said that once upon a time there was a star in a corner of the universe, and a planet circling that star, and on it some clever creatures who invented knowledge; and then they died, and the star went out, and it was as though nothing had happened (Williams, 2006b, p. 138).

Yet Williams's appeal to Nietzsche runs the risk of misleading, and we must distinguish his particular view from that which was apparently being expressed by the younger Nietzsche, from whose work Williams's paraphrase is taken: ${ }^{8}$

In some remote corner of the universe poured out into countless flickering solar systems there once was a star on which clever animals invented knowledge. That was the highest and most untruthful minute of 'world history'; but still only a minute. When nature had drawn a few breaths the star solidified and the clever animals died.

But Nietzsche goes on:

One could invent such a fable, but one would still not have sufficiently illustrated how pathetic, how shadowy and volatile, how useless and arbitrary the human intellect seems within nature. There were eternities in which it did not exist; and when it is gone nothing will have happened. For this intellect has no further mission leading beyond human life. It is human and only its owner and creator treats it as solemnly as if the hinges of the world turned on it. But if we could communicate with a gnat we would hear that it swims through the air with the same solemnity and feels as if the flying centre of this world were within it. There is nothing so reprehensible or low in nature that it would not immediately be inflated like a balloon by a small breath of that power of knowledge; and just as every porter wants to have his admirer, so the proudest of men, the philosopher, believes that the eyes of the universe are trained on his actions and thoughts like telescopes from all sides (Nietzsche, 2009, p. 253).

Certainly, this is not sentimentality. But muddle? Nietzsche's words appear distinctly more sceptical than the thrust of Williams's paraphrase. Specifically, we might read Nietzsche as saying that whilst we may be muddled, that is precisely the point and horror of it all. Williams denigrated Russell for holding on to a 'relic of a world not yet thoroughly disenchanted' (Williams, 2006b, p. 137), but Nietzsche's point, as presented in at least some of his writings, was that with regard to our self-understandings the trouble comes from the stubborn fact that we cannot yet be fully disenchanted. The metaphysical supports that maintained an earlier Christian worldview have fallen apart, but we do not yet know how to build a new structure in which to live, so we go on inadequately and dishonestly sheltering in the ruins of the old. Or to put the same point a different way: we have killed God, but comprehending what this means and acting upon it is a deed 'still more remote ... than the remotest stars' (Nietzsche, 2001, p. 120).

There are thus (at least) two ways to take Nietzsche's evocative passage. A strong reading (which appears to have been what the young Nietzsche had in mind) to the effect that realising that we are just clever creatures in a corner of the universe, and after we are gone 
it will be like nothing has happened, serves to undermine our commitment to our present values and practices by revealing their contingency, and therefore apparent arbitrariness. But there is also a weaker way of taking things: that although Nietzsche 'got it right' in his general description of humanity's status in the universe, meaning that our present values are indeed contingent, it does not follow that they are therefore rendered arbitrary, or that any loss of value need necessarily follow from recognising their contingency.

There is good reason to believe that Williams held the second, weaker view. 'The supposed problem', Williams wrote of Rorty's irony, is that the discovery that liberalism has a 'contingent history' seems 'a disappointment, which leaves us with a second best' when what we really want is a 'vindicatory history of our outlook' which gets beyond contingency and shows that our outlook is somehow correct beyond the fact that it happens to be ours. Williams rejected this view on the same grounds he rejected Russell: that it is a confusion which fails to appreciate that '[p]recisely because we are not unencumbered intelligences selecting in principle among all possible outlooks, we can accept that this outlook is ours just because of the history that has made it ours'. More fundamentally, it is not 'our job as rational agents to search for, or at least move as best we can towards, a system of ethical and political ideas which would be the best from an absolute point of view, a point of view that was free of contingent historical perspective'. Williams rejected irony by insisting that it is no accident that we and our outlook are 'in the same place at the same time', and that if we 'really understand this, deeply understand it', then there is no incoherence or loss in learning that the only point of view from which to assess our values and practices is our point of view (Williams, 2006 b, p. 193-4). That it is simply confused to think that any loss of value follows from recognising their contingency, and the fact that there is only the internal perspective of human sentiment from which to judge ethical and political matters (Fricker, 2000; Moore, 2006).

It perhaps remains an open question as to whether Williams was correct to adopt the weaker reading of the Nietzsche passage: countervailing reasons might be suggested for supposing that it is to the stronger version one should subscribe. Such a matter is wide of my present purposes, however, and I will not attempt to adjudicate on such a large question (though I will have something to say in a moment regarding whether strong sceptics can nonetheless subscribe to the liberalism of fear). We can instead focus our attention back on the question of how Williams differs from Hume. I suggest that the crucial difference lies not just in Williams's rejection of Hume's explanations, and his alleged insensitivity to diversity in moral practice and the giving of reasons to ethical agents, but in Williams's belief that taking a sceptical attitude towards our values is likely to reveal many of them to be untenable as they presently stand.

This is suggested not only by Williams's refrain that ethical life cannot be all that it seems, but in his claiming that

more is to be feared and learned from a partial scepticism in ethics, one that casts suspicion on tracts of our moral sentiments and opinions, because of their psychological origins or our actual historical situation. Some of our moral ideas may no longer do what they once did for us; some of them may not, in honest reflection, now be credible (Williams, 2014, p. 317). 
In this respect Williams's more closely resembles Nietzsche in another of his guises: that of the 'genealogist of morals', who by questioning the value of values comes to see that things he once believed about morality are untrue, unhealthy, undesirable and so on, and thus to be reconsidered and possibly rejected (Nietzsche, 1997; Williams, 2000). In his final book Truth and Truthfulness, Williams cited Hume's theory of justice as an artificial virtue as an example of how genealogies could be 'vindicatory' rather than debunking (as they typically were in Nietzsche's hands), and took this as a potential model for his own genealogical account of the value of truth and the virtues of truthfulness (Williams, 2002, pp. 21-38). Williams did not follow Hume's optimism in ethics. For Hume, once the aberration of Christianity was removed from human life, our existing sentimental practices could largely be vindicated as wholesome and transparent: in effect, a vindicatory genealogy was offered not just of the artificial virtue of justice, but of human ethical life tout court. Williams agreed with Hume that ethical life could only be constituted and understood from the inside. What he rejected was Hume's 'terminal degree of optimism' that existing commitments to much of our ethical practice - and in particular, the philosophical theory that has grown up around and in some cases warped that practice - could survive honest critical reflection upon its own status; for example, with regard to our concepts of moral responsibility, blame and established practices of punishment (Williams, 1995a; 1999, p. 256; 2006b, pp 119-26). Thus Williams did not propose a thoroughgoing ethical scepticism to the effect that all our values are jeopardised by their lack of ultimate support, but a more focused and limited scepticism threatening to destabilise specific values and beliefs that we possess but can no longer honestly believe in (Sagar, forthcoming).

Nonetheless, Williams and a modern ethical Humean like Blackburn, as well as those tempted by the stronger reading of Nietzsche, can all agree on the following: at the first-order level of critical reflection we have immediate concerns, such as the avoidance of cruelty and domination, which, because of who we are and what makes sense to us 'now and around here', propel us into a robust commitment to liberalism. Operating at this level it is quite appropriate to respond to somebody asking why they should care about cruelty and domination that (to echo another idea of Williams's) they are having 'one thought too many' (Williams, 1981, p. 18). If one doesn't already know what is wrong with such things, especially when they are happening, one cannot hope to receive an adequate answer from anyone, least of all a philosopher. Likewise, if one thinks cruelty can only be rejected if it can be invalidated metaphysically, one is missing the point of why cruelty is bad, which is not do with philosophical justifications, but with the suffering of the victim(s) and our properly functioning empathic engagement with them.

Yet the strong sceptic, tempted by the early Nietzsche, might go on to say that while this is all well and good, when stepping back from our immediate commitments to a level of second-order critical reflection, if one is sceptical regarding the possibility of ultimate support for what we do and value, then the first-order level no longer sounds enough. Despite the respectable Humean insistence that metaphysics has nothing to do with it, ethical scepticism bleeds into political-philosophic reflection: that if, as Williams insisted, in philosophy something counts as getting it right, we are impelled to find a way of holding together our existing value commitments alongside a reflective scepticism that what we do and value is ultimately contingent and thus rendered arbitrary. Williams (and, I suspect, 
ethical Humeans) would at this point reply that it is a mistake to think that there is a distinct second-order level of critical reflection generating such tensions. The upshot of Williams's response to Rorty and Russell is that there is only one level of critical reflection, which blends our aversion to cruelty, on the one hand, and our endorsement of our position in the universe, on the other, to produce a reflectively stable position that denies that contingency generates arbitrariness when it comes to what we value. Whether Williams is ultimately correct that severe scepticism can be dispelled in this manner again turns on the success or failure of further independent arguments that might be made in reply, and which cannot be considered here. (I will simply note that those aspects of Nietzsche's writings mentioned above, emphasising the importance of our collapsed enchanted Christian heritage, would certainly be pertinent.) Nonetheless, I will conclude by suggesting that although the task facing the strong sceptic is more difficult than for Williams or a Humean, such a sceptic can nonetheless come to endorse the liberalism of fear.

For the strong sceptic there is a real danger that philosophical reflection may come to undermine a commitment to liberalism (or any other political outlook): coming to believe that one's values are in some sense arbitrary may cause one to lose one's grip on why one values what one does. The answer (or perhaps better: the practical solution) for the strong sceptic may ultimately be to disengage from second-order reflection - although the price of such commitment to liberalism may therefore be the abandonment of acting truthfully. And this is unlikely to be an intellectually satisfying response from the point of view of the sincere philosopher, who is presumably preoccupied with, and animated by, questions of evaluative significance that go beyond the basic observation that we think cruelty is bad. Perhaps it is at least a prudent strategy for those doubtful that our ethical lives, and in turn our political commitments, can survive a full realisation of our true status in the universe, so evocatively described by Nietzsche. ${ }^{9}$

There is a distinct sense of paradox here for the strong sceptic: the suggestion that certain forms of philosophical reflection can undermine commitment to liberalism (or indeed any other outlook), and that a necessary requirement for preserving value commitment may be to decline from thinking too hard about its basis, despite knowing that any sincere commitment to some set of values will demand honest reflection, both about what those values are and why we hold them, especially in a world where we must negotiate the fact that others do not agree with us. A further problem, one compounding the sense of paradox, is that once one has started down the road of reflection one cannot simply get out as though from a taxicab hailed at will. Reflection may turn out to be not just corrosive, but addictive (see Fricker, 2000, pp. 90-4).

Nonetheless, insofar as the strong sceptic is able to cope with these paradoxes - and coping is likely to be more a matter of psychology and temperament than of strict philosophical reasoning - the liberalism of fear remains available to them. Thus, while Williams's ethical scepticism differed from the Humean outlook, and also from a stronger sceptical view associated with the younger Nietzsche, his political philosophy remains open to all these camps, regardless of disagreements over what follows from believing that our values lack ultimate support. One can be an ethical sceptic and a liberal, although the precise manner in which one endorses the latter will depend on how one understands the former. 


\section{Conclusions for Political Realism}

The recent growth of interest in political realism has to a large extent derived from sympathy with Williams's insistence that political philosophy should reject political moralism as a misunderstanding of what both political theory and political practice must properly be (not least with respect to each other). As another prominent realist (albeit one who is not a liberal) has put it, politics is not and can never be 'applied ethics', and so political philosophy should not be conceived of in such a way either (Geuss, 2008, p. 6). Yet there is another recent and prominent approach that seeks to bypass the question of whether or not there are ultimate supports for our values, instead proposing that liberalism can be understood as a freestanding political practice. This was the option pursued by John Rawls in his later work: a 'Kantian constructivism' whereby admissible political reasons are stipulated to be only those which can be brought into engagement on the basis not of thoroughgoing ethical convictions (in Rawls's language, 'comprehensive doctrines'), but of reasons in principle accessible to all who are willing to be 'reasonable' by the standards of liberalism, understood in conditions of late Western modernity (Rawls, 1993, pp. 89-172).

Many realists will likely agree with Williams that Rawls's political liberalism remains a form of political moralism, insufficiently attentive to the demands of a truly political political philosophy (Williams, 2005, pp. 2-3; Waldron, 2013; but also Gledhill, 2012; Jubb, forthcoming). More specifically, the pitfall of Rawls's approach from a realist perspective is that it threatens fatally to depoliticise the political. In addition to the heavily and controversially rationalist premises of the argument, and the deeply questionable belief that there are any reasons independent of ethical conviction that could gain traction in anything that resembles the frequently emotive and ignoble clash of politics (as opposed to a well regulated court of law, or Williams's example of the seminar room, which seem closer to Rawls's model), there is the implausibility of this as a model for politics tout court. Alongside the competition for power and riches, politics just is about the contest between rival ethical visions. As a result there simply is no sanitised space of political reasons from which to construct a politics sufficiently autonomous from ethical conviction. Taken on its own terms, the later Rawls's approach offers the potential simply to bypass the question of ethical scepticism (in either its strong or weak guise) and its relation to liberalism. Unfortunately, there is good reason to suspect that such terms cannot in fact be taken.

Happily, and as Fabian Freyenhagen has demonstrated, Williams's liberalism of fear itself offers a more promising avenue by which to establish a political conception (in the late Rawlsian sense) than Rawls's own account: a conception of legitimacy (although admittedly not of justice) that provides public reasons to people of very different comprehensive doctrines, which they can further support for their own reasons. However 'it would not do so on the grounds of a moral conception of personhood or on the grounds of the quasi-transcendental presuppositions of discourses, but instead on the grounds of historical experience' (Freyenhagen, 2011 p. 336; Wenar, 1995) These reasons could certainly be moral, but could also be merely prudential, something disallowed by Rawls on the grounds that such agreement would amount only to a mere modus vivendi, but to which Williamsinspired realists would likely reply is a significant political and historical achievement, and one well worth having (Williams, 2005, p. 2). As I have demonstrated above, the liberalism 
of fear is open to several different views, which while agreeing that there are no ultimate supports for what we do and value, disagree about what follows from that. And the door is of course just as open to those who take less sceptical views of the status of our moral and political values. This is a further strength of the liberalism of fear: grounded in the minimal materials of historical experience and an aversion to the evils of cruelty and domination, it can welcome many different perspectives precisely because it does not demand a thoroughgoing adherence to particular, abstract or controversial philosophical starting points.

To conclude, I offer two further remarks on the subject of political realism. The first is that although many self-described realists have taken inspiration from Williams, a note of caution is in order. Williams was notoriously sceptical of the construction of ethical theories, believing that these not only failed in their usual ambitions of providing holistic accounts of our ethical lives, but that their prescriptive tendencies often served to warp and confuse, rather than clarify, our normative practices (Williams, 1995b; 2005, p. 52). He suggested that making progress in our ethical thought would involve moving away from thinking in terms of knowledge, and towards building a renewed 'confidence' in our ethics. However, this was mostly a practical task, with philosophy playing the largely negative role of removing the obstacles philosophy itself has previously put in the way (Fricker 2000; Hall, 2014; Williams 1993 [1985], pp. 170-1). This current in Williams's thought is likely to stand in tension with the construction of realist 'theories' of politics (Honig and Stears, 2011; Rossi, 2012; Sangiovanni, 2008; Sleat, 2013). Those sympathetic to the demands of 'realism' should therefore be cautious in drawing upon Williams's work, for whom 'an approach which gives greater autonomy to distinctively political thought' was unlikely to have been the same thing as coming up with a theory of politics, in anything like the traditional sense, no matter how realistic. By contrast, a political realism genuinely faithful to Williams's ambitions is likely to be more interested in developing the idea of political confidence, including its relations to ethical confidence, than in the construction of philosophical theory (Hall, 2014).

In similar vein, I offer a final suggestion regarding the future direction of a more realistic approach to political philosophy inspired by Williams. Commitment to the liberalism of fear is generated at what I have called the first-order level of critical reflection, and is open to those holding different views about what obtains at the second-order level (assuming such a second-order level even exists once we get clear on what is at issue). As a result, the liberalism of fear is not only philosophically minimal in its foundations, but when working out what an approach that gives greater autonomy to political thought looks like in more developed practice, it is possible and perhaps likely that if done well it will turn out not to look much like philosophy as traditionally undertaken. If we want to know more about our political history and the best ways of preventing cruelty, progress is most likely to be made not by considering values and concepts in the abstract, but in examining what has been found to work in experience, and considering what the best thinkers of related but traditionally distinct disciplines have to teach us. Thus, the academic future of the liberalism of fear may turn out to lie more in the disciplines of jurisprudence, the history of political thought, and constitutional analysis, while making the effort to incorporate an appreciation of the findings of psychology and sociology, than in what is traditionally 
regarded as philosophy (Waldron, 2013). I see no reason to think that there is anything wrong with that.

\section{(Accepted: 17 August 2014)}

\section{About the Author}

Paul Sagar is a Junior Research Fellow elect at King's College, Cambridge. His research interests include the history of political thought (especially that of the eighteenth century) and contemporary political theory, and he has recently completed a doctoral thesis on the political philosophy of David Hume. Previous publications include 'Sociability, Luxury and Sympathy: The Case of Archibald Campbell' (History of European Ideas 39:6, 2013), 'Minding the Gap: Bernard Williams and David Hume on Living an Ethical Life' (Journal of Moral Philosophy, forthcoming) and 'Of Mushrooms and Method: History and the Family in Hobbes's Science of Politics' (European Journal of Political Theory, forthcoming). Paul Sagar, 711 King's College, University of Cambridge, Cambridge CB2 1ST, United Kingdom; email: prs49@cam.ac.uk

\section{Notes}

The excessively long period it took to get this article right would have been much reduced if $\mathrm{I}$ had paid better attention to the suggestions of Nakul Krishna, Hallvard Lillehammer, Richard North and especially Ed Hall. Nonetheless, I got there eventually, and to all of them I am grateful. An earlier version of the article was presented at the Cambridge Political Philosophy Workshop and the 2012 MANCEPT workshop series, where the comments of Nicholas Vrousalis, Lorna Finlayson, Clif Mark, Enzo Rossi and Derek Edyvane were most helpful. Support also came from Istvan Hont, Richard Bourke, Marc Steers and Duncan Kelly. I am especially grateful to the three Political Studies anonymous reviewers, who steered me away from a number of serious errors. Research for this article was undertaken while I was the recipient of an Arts and Humanities Research Council PhD studentship at the University of Cambridge, and was later supported by the Cambridge Faculty of History's Prince Consort and Thirlwall fund.

1 For example, Cohen (2003); Estlund (2008); Gledhill (2012); Philp (2010; 2012); Sangiovanni (2008); Sigwart (2013); Stears (2005); Swift and White (2008), as well as the essays collected in Floyd and Stears (2011) and the special edition of the European Journal of Philosophy (2010, 9 (4)) dedicated to 'realism'. For an overview of 'realist' political theory, see Rossi and Sleat (2014).

2 Bavister-Gould (2013); Frazer (2010); Freeden (2012); Honig and Stears (2011); Jubb (forthcoming); Larmore (2013); Rossi (2013); Sangiovanni (2009); Sleat (2007; 2010).

3 In modern conditions this will now usually be a state, which in Weber's terms successfully monopolises the legitimate use of force within a given territory. But it may not always have been or need to be.

4 Defenders of 'negative dialectic' and 'immanent critique' approaches to politics would question this. I do not consider such responses here. For an overview, see Geuss (1981).

5 Critics such as Freeden are thus mistaken in accusing Williams of an inability to recognise the plurality of political-philosophic outlooks within modern liberal society (Freeden, 2012). Williams would have no problem recognising that many people are not liberals, and, on the other hand, he would likely have agreed with Rawls that one of the proper functions of political philosophy is the 'Hegelian' task of reconciling us to our circumstances when those circumstances deserve our reconciliation (Rawls, 2001, p. 3).

6 As we shall see below, the liberalism of fear is also ecumenical with regard to nonsceptical positions, and this is another of its strengths.

7 Although Rorty (1989, p. 85) claims he will address the objection that 'the same person cannot be, in alternative moments, Nietzsche and J. S. Mill', he in fact does not address this, instead diverting the discussion into the claim that opponents of irony mistakenly accuse it of licensing cruelty, suggesting that avoidance of humiliation is the chief political goal. This is irrelevant for explaining how one can be both Nietzsche and J. S. Mill - i.e. an ethical sceptic and a liberal.

8 It is important to note that Nietzsche may well have changed his position in later life and moved to something more like Williams's mitigated scepticism. I cannot address this large interpretative question here. For a discussion of Nietzsche's later views, see especially Pippin (2010).

9 Critics might reply that it is not so much prudent as (self)-deceitful, and indeed that if the young Nietzsche is right the difficult question arises of why we should want to be prudent.

\section{References}

Bavister-Gould, A. (2013) 'Bernard Williams: Political Realism and the Limits of Legitimacy', European Journal of Philosophy, 21 (4), 593-610.

Blackburn, S. (1986) 'Making Ends Meet', Philosophical Books, 27 (4), 194-201.

Blackburn, S. (1998) Ruling Passions: A Theory of Practical Reasoning. Oxford: Oxford University Press.

Blackburn, S. (2005) Truth: A Guide for the Perplexed. London: Allen Lane.

Cohen, G. A. (2003) 'Facts and Principles', Philosophy and Public Affairs, 31 (3), 211-45.

Estlund, D. (2008) Democratic Authority: A Philosophical Framework. Princeton, NJ: Princeton University Press.

Floyd, J. and Stears, M. (2011) Political Philosophy versus History? Cambridge: Cambridge University Press. 
Forrester, K. (2012) 'Judith Shklar, Bernard Williams and Political Realism', European Journal of Political Theory, 11 (3), 247-72.

Frazer, E. (2010) 'What's Real in Political Philosophy', Contemporary Political Philosophy, 9 (4), 490-507.

Freeden, M. (2012) 'Interpretative Realism and Prescriptive Realism', Journal of Political Ideologies, 17 (1), 1-11.

Freyenhagen, F. (2011) 'Taking Reasonable Pluralism Seriously: An Internal Critique of Political Liberalism', Politics, Philosophy and Economics, 10 (3), 323-42.

Fricker, M. (2000) 'Confidence and Irony', in E. Harcourt (ed.), Morality, Reflection and Ideology. Oxford: Oxford University Press, pp. 87-112.

Geuss, R. (1981) The Idea of a Critical Theory: Habermas and the Frankfurt School. Cambridge: Cambridge University Press.

Geuss, R. (2008) Philosophy and Real Politics. Princeton, NJ: Princeton University Press.

Gledhill, J. (2012) 'Rawls and Realism', Social Theory and Practice, 38 (1), 55-82.

Hall, E. (forthcoming) 'The Basic Legitimation Demand: A Defence', Political Studies, doi: 10.1111/1467-9248.12070.

Hall, E. (2014) 'Contingency, Confidence and Liberalism in the Political Thought of Bernard Williams', Social Theory and Practice, 40 (4), 545-69.

Honig, B. and Stears, M. (2011) 'The New Realism: From Modus Vivendi to Justice', in J. Floyd and M. Stears (eds), Political Philosophy versus History? Cambridge: Cambridge University Press, pp. 177-205.

Jubb, R. (forthcoming) 'Playing Kant at the Court of King Arthur', Political Studies, doi: 10.1111/1467-9248.12132.

Larmore, C. (2013) 'What is Political Philosophy?', Journal of Moral Philosophy, 10 (3), 276-306.

Moore, A. W. (2006) 'Maxims and Thick Ethical Concepts', Ratio, 19 (2), 129-47.

Nietzsche, F. (1997) K. Ansell-Pearson (ed.), On the Genealogy of Morality. Cambridge: Cambridge University Press.

Nietzsche, F. (2001) B. Williams (ed.), The Gay Science. Cambridge: Cambridge University Press.

Nietzsche, F. (2009) 'On Truth and Lie in an Extra-Moral Sense', in R. Guess and A. Nehamas (eds), Writings from the Early Notebooks. Cambridge: Cambridge University Press, pp. 253-64.

Philp, M. (2010) 'What is to be Done? Political Theory and Political Realism', European Journal of Political Theory, 9 (4), 466-84.

Philp, M. (2012) 'Realism without Illusions', Political Theory, 40 (5), 629-49.

Pippin, R. (2010) Nietzsche, Psychology and First Philosophy. Chicago, IL: University of Chicago Press.

Rawls, J. (1993) Political Liberalism. New York: Columbia University Press.

Rawls, J. (2001) Justice as Fairness: A Restatement. Cambridge, MA: Belknap Press.

Rorty, R. (1989) Contingency, Irony, and Solidarity. Cambridge: Cambridge University Press.

Rossi, E. (2012) 'Justice, Legitimacy and (Normative) Authority for Political Realists', Critical Review of International Social and Political Philosophy, 15 (2), 149-64.

Rossi, E. (2013) 'Consensus, Compromise, Justice and Legitimacy', Critical Review of International Social and Political Philosophy, 16 (4), 557-72.

Rossi, E. and Sleat, M. (2014) 'Realism in Normative Political Theory', Philosophical Compass, 9 (10), 689-701.

Sagar, P. (forthcoming) 'Minding the Gap: Bernard Williams and David Hume on Living an Ethical Life', Journal of Moral Philosophy, 11 (5), 615-38.

Sangiovanni, A. (2008) 'Justice and the Priority of Politics to Morality', Journal of Political Philosophy, 16 (2), $137-64$.

Sangiovanni, A. (2009) 'Normative Political Theory: A Flight from Reality?', in D. Bell (ed.), Political Thought and International Relations: Variations on a Realist Theme. Oxford: Oxford University Press, pp. 219-39.

Shklar, J. (1984) Ordinary Vices. Cambridge, MA: Belknap Press.

Shklar, J. (1998) 'The Liberalism of Fear', in S. Hoffmann (ed.), Political Thought and Political Thinkers. Chicago, IL: Chicago University Press, pp. 3-20.

Sigwart, H. J. (2013) 'The Logic of Legitimacy: Ethics in Political Realism', Review of Politics, 75 (3), 407-32.

Sleat, M. (2007) 'Making Sense of Our Political Lives: On the Political Philosophy of Bernard Williams', Critical Review of International Social and Political Philosophy, 10 (3), 389-98.

Sleat, M. (2010) 'Bernard Williams and the Possibility of a Realist Political Theory', European Journal of Political Theory, 9 (4), 485-503.

Sleat, M. (2013) Liberal Realism: A Realist Theory of Liberal Politics. Manchester: Manchester University Press.

Stears, M. (2005) 'The Vocation of Political Theory', European Journal of Political Theory, 4 (4), 325-50.

Swift, A. and White, S. (2008) 'Political Theory, Social Science and Real Politics', in D. Leopold and M. Stears (eds), Political Theory: Methods and Approaches. Oxford: Oxford University Press, pp. 49-69.

Waldron, J. (2013) 'Political Political Theory: An Inaugural Lecture', Journal of Political Philosophy, 21 (1), 1-23.

Wenar, L. (1995) 'Political Liberalism: An Internal Critique', Ethics, 106 (1), 32-62.

Williams, B. (1981) Moral Luck. Cambridge: Cambridge University Press, pp. 54-70.

Williams, B. (1986) 'Reply to Simon Blackburn', Philosophical Books, 27 (4), 206-7.

Williams, B. (1993 [1985]) Ethics and the Limits of Philosophy. London: Routledge.

Williams, B. (1995a) 'How Free Does the Will Need to Be?', in B. Williams, Making Sense of Humanity and Other Philosophical Papers. Cambridge: Cambridge University Press, pp. 3-21.

Williams, B. (1995b) 'The Point of View of the Universe: Sidgwick and the Ambitions of Ethics', in B. Williams, Making Sense of Humanity and Other Philosophical Papers. Cambridge: Cambridge University Press, pp. 153-71.

Williams, B. (1999) 'Seminar with Bernard Williams', Ethical Persepctives, 6 (3-4), 243-65. 
Williams, B. (2000) 'Naturalism and Genealogy', in E. Harcourt (ed.), Morality, Reflection and Ideology. Oxford: Oxford University Press, pp. 148-61.

Williams, B. (2002) Truth and Truthfulness: An Essay in Genealogy. Princeton, NJ: Princeton University Press.

Williams, B. (2005) G. Hawthorn (ed.), In the Beginning was the Deed. Princeton, NJ: Princeton University Press.

Williams, B. (2006a) M. Burnyeat (ed.), A Sense of the Past. Princeton, NJ: Princeton University Press.

Williams, B. (2006b) A. W. Moore (ed.), Philosophy as a Humanistic Discipline. Princeton, NJ: University Press.

Williams, B. (2014) 'The Need to be Sceptical', in B. Williams, Essays and Reviews. Princeton, NJ: Princeton University Press, pp. 311-17. 